DOI: $10.20472 /$ IAC.2018.039.020

\title{
PIERRE JOUBERT
}

Vaal University of Technology, South Africa

\section{PERCEIVED ORGANISATIONAL SUPPORT, JOB SATISFACTION AND ORGANISATIONAL CITIZENSHIP BEHAVIOUR OF SOUTH AFRICAN POLICE SERVICE OFFICIALS}

\begin{abstract}
:
The current research study is premised on theoretical frameworks that are embedded in different human behaviour studies, which have been conducted by researchers in the past. The different theories underlying the research will be discussed. This study aims to provide a more complete picture of the Organisational Citizenship Behaviour (OCB), Perceived Organisational Support (POS) and Job Satisfaction (JS), in the South African Police Service (SAPS) and contribute towards cultivating a more professional corps of SAPS officials. A quantitative and descriptive research method was used to investigate a sample size of 300 police officials working at police stations in the Tygerberg Cluster of SAPS. Data was collected with the aid of a structured questionnaire. The reliability and validity were increased by conducting a pre-test and a pilot study prior to the final study. A factor analytic procedure was followed for each of the three constructs. The results of the correlation analysis revealed a negative relationship between POS and OCB and between JS and OCB. The data, however, indicated positive correlations between JS and POS. Findings and recommendations in this study are important to government, SAPS, individual members and commanders as it provides information regarding types of activities and interventions to enhance perceived organisational support, job satisfaction and behaviours associated with organisational citizenship.
\end{abstract}

\section{Keywords:}

Organisational support, job satisfaction, organisational citizenship behaviour

JEL Classification: M54 